\title{
DESCRIPTIVE ANALYSIS OF TRIP MAKING CHARACTERISTICS IN ADO-EKITI, EKITI STATE, NIGERIA
}

\author{
Olufikayo Oluwaseun Aderinlewo* \\ Date received: 31/03/2020 Date accepted: 03/09/2020 \\ *Corresponding author's email: oluade2010@gmail.com \\ DOI: $10.33736 /$ jcest. 2612.2020
}

Civil Engineering Department, Federal University of Technology Akure, Ondo State, Nigeria.

\begin{abstract}
In this study, the trip making characteristics in Ado-Ekiti, Ekiti State, Nigeria are descriptively analysed. The city was divided into nine zones out of which 1,597 households were interviewed out of a total population of 15,945 households Trips generated and attracted to each zone of the city of Ado-Ekiti for business and non-business purposes were determined. The relationship between the number of trips generated and land use factors were also determined. The effects of income on car ownership and the effects of both on trip making pattern were established while trips were accrued to various modes of transport in the city. The study showed that land-use is the main factor responsible for trips production and attraction. It was established that commercial zones attracted the highest number of trips generated per week for both business and non-business trips while high and medium residential zones produced the highest number of business and non-business trips. In contrast, public zone produced the lowest number of business and non-business trips. Finally, the study shows that income is directly proportional to car ownership and that both income and car ownership have considerable effects on trip generation.
\end{abstract}

Copyright (C) 2020 UNIMAS Publisher. This is an open access article distributed under the Creative Commons Attribution-NonCommercial-ShareAlike 4.0 International License which permits unrestricted use, distribution, and reproduction in any medium, provided the original work is properly cited.

Keywords: Generated, attracted, business, trips, land-use

\subsection{INTRODUCTION}

An analysis of trip making characteristics in Ado-Ekiti is the study of movement of people within the city. It encompasses determining the purpose of trips either for business or non-business purposes, origin and destination of trips, frequency with which trips are made, the economy of making the trips and the available transport modes for making trips in the city.

Ado-Ekiti had relatively small population and low availability of vehicles before the creation of Ekiti state in October 1996. As a result of being made the capital of the state, people from different parts of the state and country (Nigeria) gradually migrated into the city to seek government work. Also, aspiring politicians and business tycoons moved to the city with the hope of finding a steady source of income and a decent standard of living. As a result of considerable growth in population, land use increased for ministry offices, industries, schools, business centers, police and military barracks, recreational centers and residential quarters.

The transportation system in Ado-Ekiti was developed to serve people so as to undertake their economical, social and cultural activities [1]. Hence, it has to be efficient by being able to balance a variety of usually conflicting requirements that the society in general considers to be important to it. These requirements include cost consideration, convenience and protection related to making a trip. Consequently, the road transportation system would include not only the roads but also vehicles, passengers and cargo which are all interdependent [2].

Hence, transportation depends greatly on land use which include residential, commercial, industrial, recreational, institutional and any other diverse ways in which land is being put to use. Land use and transportation planning are therefore closely related because the demand for travel facilities is a function of human land activity and in contrast the provision of transport facilities has often promoted land use activity [3]. 
Trip studies in this case include the study of the purpose for making trips, origin and destination of the trips within the city, frequency of making trips, the economy of making trips and finally the available transport modes in the city [4]. The study area, Ado-Ekiti, is divided into traffic zones for which trip attractions and productions are estimated. In addition, the relationship between travel patterns and land use, the relationship between travel and socio-economic factors and the relationship between travel patterns and modes of transport in Ado-Ekiti are determined.

\subsection{BACKGROUND LITERATURE}

The process of analyzing trips requires travel forecasting which takes place through a model comprising of four stages namely trip generation, trip distribution, modal split and traffic assignment. Trip generation attempts to determine the connection between trip making and land use and predicts the number of trips per time period made to and from a given zone. Trip distribution is concerned with finding the zones to or from which the generated trips are directed. Modal split is concerned with determination of the particular mode of transportation used by trip makers while traffic assignment involves assigning the distributed volumes of trips to individual network links [5].

In trip generation analysis, three approaches are commonly used for developing models namely regression analysis, trip rate analysis and cross-classification analysis [6]. Trip generation models are a set of mathematical equations that collectively relate travel patterns to land use, residential density, socioeconomic characteristics, demographic characteristics and other parameters of the transport system.

In case of distribution, many mathematical models have been tried such as linear programming formulations, regression models, growth factor models, opportunity models and gravity type models (which is the most popular). In the case of modal split, three types of models are also used namely tripend models, trip interchange models and individual mode choice models [7]. Lastly, trip assignment techniques used include all-or-nothing, iterative, incremental, user-equilibrium and system optimal traffic assignments [8]. The major movement within urban areas, related to the travel available for urban passenger transportation, are mainly land-based and include private transportation (walking and private vehicles) and various public transportation services of which some are highway-based (such as regular city buses, taxi or cabs.

Initially, modern-era cities were pedestrian oriented. Even after the development of mechanized long distance transportation system such as rail roads, the size of most cities was sufficiently small for people to traverse by walking. Private transportation in the form of horseback was sufficient for longer distances. In addition, significant differences in the pattern of urban travel, however necessitated the development of more refined techniques. An important difference was the fact that in urban areas, street capacities between various parts of the city involve multiple rather than single routes [9].

At present, large urban areas in Nigeria are suffering from transportation congestion. Changes in transport mode frequently produce changes in land-use pattern. Recently, the availability of private transport has led to the growth of housing development which cannot be economically served by public transport. Hence there is a need to carry out a transportation survey to be able to meet demand with supply of transportation services [10].

The transportation survey is an attempt to take an inventory of trip making pattern as it exists at the present time together with details of travel facilities available, land-use activities and socio-economic factors that can be considered to influence travel [11]. This is followed by the production of a mathematical model 
which can be used to explain the relationship between the observed travel pattern and socio-economic factors obtained by the transportation survey, predict transportation needs and evaluate alternative transportation plans. Next, the existing land-use characteristics are inserted into the trip generation procedure in which the trips are distributed, assigned and a modal split decision is carried out. It is then possible to forecast the travel needs of future land-use and transport plans once confidence in the ability of the developed models is established.

At this stage, it is important to make some basic definitions. A trip is a one-way person movement by one or more modes of travel and each trip has an origin and a destination. Most surveys divide trips into homebased and non-home based trips. All trips which have one end at the home are said to be generated by the home and other ends of trip is said to be attracted to the zone in which it terminates. In this study, trips are divided into business and non-business trips where business trips are work related and the converse applies to non-business trips.

The form of the relationship connecting trip generation, land use and socio-economic factors depends upon the basic framework of the transportation process [12]. If the study is designed to use trip end modal split models which allocates trips to differing modes of transport before the distribution of trips between the traffic zones, then the trip generation models are designed to predict movement by differing modes of transport or travel. Conversely, a trip interchange model (which predicts person movement in terms of total person movement by all modes of travel) is required when trips are distributed between zones before decision is made regarding the modes of travel.

Trip generation equations have as their dependent variable the number of trips generated per person or per household for different trip purposes while independent variables are the land use and socio-economic factors that are considered to affect trip making. Land use is of course a major consideration in the generation of trips. Similarly, the type of activity and the number of workers employed per unit area will influence trip generation in areas where commercial or industrial land use is of importance. Other factors connected with home that are considered to influence trip generation rates are the family size, income, motor vehicle ownership and socio-economic status of the head of the family being considered.

\subsection{METHODOLOGY}

The complete area of investigation, Ado-Ekiti, was divided into nine zones. These zones are as follows: high residential, medium residential, low residential, commercial, educational, industrial, military, public and recreational zones. The methods used in collecting data ranged from simple observation to extensive home interviews by administering questionnaires to selected households in each zone. The households interviewed were selected using random number generation sampling method which amounted to ten percent of households in the study area out of a total of fifteen thousand nine hundred and forty-five households.

The following information was extracted from the questionnaires administered:

A. Origins and destinations of both the business and non-business trips of the respondents and members of their family

B. Car ownership

C. Modes of transport of respondents to places of work and from their places of work to their various homes.

D. Number of persons per household

E. Household income 


\subsection{DESCRIPTION OF THE STUDY AREA}

Ado-Ekiti is the capital of Ekiti state, located south-west of Nigeria. Ekiti was declared a state on October 1, 1996 alongside five others by the then military government. Ado-Ekiti is situated about one hundred and six kilometers east of Ibadan City and about four hundred and seven kilometers north-east of Lagos.

Ado-Ekiti lies on latitude $7^{\circ} 38^{\prime} 0^{\prime \prime}$ North of the equator and longitude $5^{\circ} 13^{\prime} 0^{\prime \prime}$ East of the Greenwich Meridian. It is about two hundred and fifty meters above sea level. The city enjoys good accessibility from other surrounding cities especially Akure (the capital of Ondo state) and Osogbo (the capital of Osun state) as a result of its good regional positioning and geographical location.

\subsection{RESULTS AND DISCUSSION}

The number of households to interview in each zone was obtained by multiplying the number of households in each zone by 10 percent as shown in Table 1 . Table 1 shows that 1,597 households were interviewed out of a total population of 15,945 households.

Table 1. Distribution of Households in zones

\begin{tabular}{|l|c|c|}
\hline Zones & Number of Households & Number of Households Interviewed \\
\hline Low Residential & 1200 & 120 \\
\hline Medium Residential & 4975 & 498 \\
\hline High Residential & 4196 & 420 \\
\hline Commercial & 2478 & 248 \\
\hline Recreational & 697 & 70 \\
\hline Educational & 985 & 99 \\
\hline Industrial & 738 & 74 \\
\hline Military & 228 & 23 \\
\hline Public & 448 & 45 \\
\hline Total & 15945 & 1597 \\
\hline
\end{tabular}

Thereafter, the four stage process of the transport model was implemented. The total number of trips generated and attracted to the zones are as shown in Table 2. Table 2 presents the total number of business and non-business trips per week generated from each zone and attracted from other zones and it shows that high residential zones generated the highest number of business trips per week followed by medium residential and commercial zones while public and recreational zones generated the least business trips respectively.

Table 2 also shows that commercial zones attracted the highest number of business trips per week followed respectively by recreational zones, medium residential zones and high residential zones while industrial zones attracted the least business trips. Medium residential zones generated the highest number of non-business trips per week followed respectively by high residential zones and commercial zones while military and recreational zones generated the least non-business trips. It is also apparent that commercial zones attracted the highest number of non-business trips followed by high residential zones while public, industrial and educational zones attracted the least non-business trips. 
Table 2. Total Trips generated and attracted

\begin{tabular}{|l|c|c|c|c|}
\hline \multirow{2}{*}{ Zones } & \multicolumn{2}{|l|}{ Business Trips per week } & \multicolumn{2}{l|}{ Non-Business Trips per week } \\
\cline { 2 - 5 } & $\begin{array}{l}\text { Total trips } \\
\text { generated }\end{array}$ & $\begin{array}{l}\text { Total trips } \\
\text { attracted }\end{array}$ & $\begin{array}{l}\text { Total trips } \\
\text { generated }\end{array}$ & Total trips attracted \\
\hline Low Residential & 12,720 & 26,921 & 5,520 & 14,856 \\
\hline Medium Residential & 90,454 & 42,540 & 64,095 & 12,442 \\
\hline High Residential & 126,000 & 41,518 & 45,360 & 26,448 \\
\hline Commercial & 74,648 & 68,732 & 20,178 & 64,799 \\
\hline Recreational & 3,960 & 46,904 & 4,217 & 12,229 \\
\hline Educational & 7,975 & 41,213 & 5,934 & 3,872 \\
\hline Industrial & 9,102 & 12,526 & 6,364 & 4,747 \\
\hline Military & 12,573 & 21,749 & 4,356 & 14,810 \\
\hline Public & 2,208 & 14,135 & 1,344 & 5,848 \\
\hline
\end{tabular}

The relationship between the level of income of the households in each zone and car ownership was also examined as shown in Table 3. Table 3 shows how household income affects car ownership in each zone and it indicates that as income increases more households are able to own or afford a car with car ownership reaching a maximum of 40 for a corresponding number of households of 44 and income level exceeding $\$ 100,000$ in medium residential zones. However, in terms of average number of cars per household, public and residential zones have the highest average number of vehicles per household of 1 for income level exceeding 100,000 .

Table 3. Income distribution and car ownership in the zones

\begin{tabular}{|c|c|c|c|c|c|c|c|c|c|c|c|c|c|c|c|c|c|c|}
\hline \multirow[t]{2}{*}{$\begin{array}{l}\text { Income } \\
\text { Classes } \\
\text { (\#)/Month }\end{array}$} & \multicolumn{2}{|c|}{$\begin{array}{c}\text { Low } \\
\text { Residential } \\
\text { Zone }\end{array}$} & \multicolumn{2}{|c|}{$\begin{array}{l}\text { Medium } \\
\text { Residential } \\
\text { Zone }\end{array}$} & \multicolumn{2}{|c|}{$\begin{array}{c}\text { High } \\
\text { Residential } \\
\text { Zone }\end{array}$} & \multicolumn{2}{|c|}{$\begin{array}{c}\text { Commercial } \\
\text { Zone }\end{array}$} & \multicolumn{2}{|c|}{$\begin{array}{c}\text { Educational } \\
\text { Zone }\end{array}$} & \multicolumn{2}{|c|}{$\begin{array}{c}\text { Industrial } \\
\text { Zone }\end{array}$} & \multicolumn{2}{|c|}{$\begin{array}{c}\text { Public } \\
\text { Zone }\end{array}$} & \multicolumn{2}{|c|}{$\begin{array}{c}\text { Military } \\
\text { Zone }\end{array}$} & \multicolumn{2}{|c|}{$\begin{array}{c}\text { Recreational } \\
\text { Zone }\end{array}$} \\
\hline & 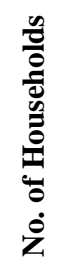 & 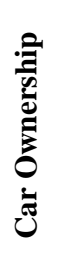 & 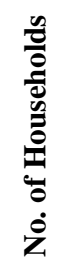 & 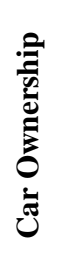 & 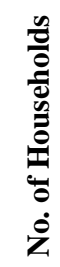 & 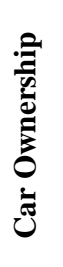 & 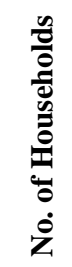 & 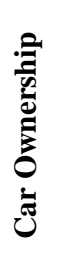 & 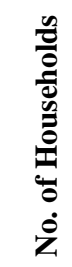 & 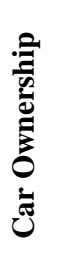 & 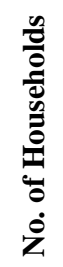 & 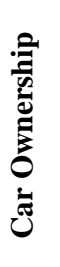 & 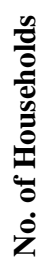 & 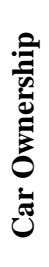 & 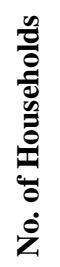 & 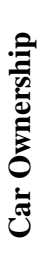 & $\begin{array}{l}\frac{n}{0} \\
\frac{0}{0} \\
\frac{0}{0} \\
0 \\
0 \\
0 \\
\dot{0} \\
\dot{0}\end{array}$ & 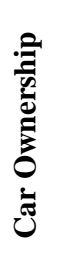 \\
\hline$<10,000$ & 1 & 0 & 21 & 0 & 18 & 0 & 10 & 0 & 0 & 0 & 2 & 0 & 0 & 0 & 0 & 0 & 2 & 0 \\
\hline $\begin{array}{l}10,000- \\
25,000\end{array}$ & 4 & 0 & 38 & 0 & 32 & 0 & 23 & 0 & 3 & 0 & 4 & 0 & 0 & 0 & 3 & 0 & 5 & 0 \\
\hline $\begin{array}{l}25,001- \\
40,000\end{array}$ & 9 & 0 & 62 & 2 & 62 & 0 & 59 & 0 & 5 & 0 & 8 & 0 & 0 & 0 & 5 & 0 & 9 & 0 \\
\hline $\begin{array}{l}40,001- \\
55,000\end{array}$ & 13 & 2 & 101 & 7 & 91 & 2 & 54 & 0 & 10 & 0 & 16 & 0 & 3 & 0 & 10 & 0 & 12 & 2 \\
\hline $\begin{array}{l}55,001- \\
70,000 \\
\end{array}$ & 20 & 8 & 94 & 9 & 80 & 6 & 38 & 3 & 13 & 1 & 14 & 2 & 6 & 2 & 13 & 1 & 17 & 9 \\
\hline $\begin{array}{l}70,001- \\
85,000\end{array}$ & 28 & 18 & 78 & 16 & 65 & 13 & 31 & 10 & 15 & 2 & 12 & 4 & 11 & 7 & 15 & 2 & 19 & 11 \\
\hline $\begin{array}{l}85,001- \\
100,000\end{array}$ & 23 & 22 & 60 & 25 & 41 & 24 & 19 & 13 & 12 & 6 & 11 & 8 & 12 & 10 & 12 & 6 & 18 & 15 \\
\hline$>100,000$ & 22 & 21 & 44 & 40 & 31 & 28 & 15 & 14 & 11 & 9 & 7 & 6 & 13 & 13 & 11 & 9 & 17 & 17 \\
\hline
\end{tabular}


The modal split for the different zones for business and non-business trips were determined as shown in Tables 4 to 21 . Table 4 shows that the highest number of business trips per week generated from low residential zones is attracted to public zones while military zones attracted the least number.

Table 4. Modal split for business trips with low residential zone as origin

\begin{tabular}{|l|c|c|c|c|c|c|}
\hline \multirow{2}{*}{ Destination } & \multirow{2}{*}{$\begin{array}{c}\text { Trips per } \\
\text { week }\end{array}$} & $\begin{array}{c}\text { Private } \\
\text { vehicle }\end{array}$ & \multirow{2}{*}{ Trek } & \multicolumn{3}{|c|}{ Public transport } \\
\cline { 5 - 7 } & 1200 & 360 & 0 & 480 & 0 & 360 \\
\hline $\begin{array}{l}\text { Medium } \\
\text { Residential }\end{array}$ & 840 & 240 & 0 & 360 & 120 & 120 \\
\hline $\begin{array}{l}\text { High } \\
\text { Residential }\end{array}$ & & & & & & Mus \\
\hline Commercial & 2400 & 720 & 0 & 1440 & 0 & 240 \\
\hline Recreational & 600 & 120 & 0 & 480 & 0 & 0 \\
\hline Educational & 1940 & 740 & 0 & 720 & 480 & 0 \\
\hline Industrial & 360 & 120 & 0 & 120 & 120 & 0 \\
\hline Military & 480 & 120 & 0 & 360 & 0 & 0 \\
\hline Public & 5400 & 840 & 960 & 2160 & 0 & 1440 \\
\hline
\end{tabular}

With regards to non-business trips, Table 5 shows that the highest number generated per week from low residential zones is attracted to public zone and the least to educational zones. This is due to the fact that civil servants mainly reside in low residential zones and they work in public zones. The closeness of public zones to low residential zones acts as a "magnet" that draws trips from low residential zones to public zones.

Table 5. Modal split for non-business trips with low residential zone as origin

\begin{tabular}{|l|c|c|c|c|c|c|}
\hline \multirow{2}{*}{ Destination } & \multirow{2}{*}{$\begin{array}{c}\text { Trips per } \\
\text { week }\end{array}$} & $\begin{array}{c}\text { Private } \\
\text { vehicle }\end{array}$ & \multirow{2}{*}{ Trek } & \multicolumn{3}{|c|}{ Public transport } \\
\cline { 4 - 7 } & & & Cab & Bus & Motor cycle \\
\hline $\begin{array}{l}\text { Medium } \\
\text { Residential }\end{array}$ & 360 & 120 & 0 & 120 & 0 & 120 \\
\hline $\begin{array}{l}\text { High } \\
\text { Residential }\end{array}$ & 1320 & 240 & 120 & 840 & 120 & 0 \\
\hline Commercial & 1320 & 360 & 0 & 720 & 0 & 240 \\
\hline Recreational & 360 & 120 & 0 & 240 & 0 & 0 \\
\hline Educational & 120 & 120 & 0 & 0 & 0 & 0 \\
\hline Industrial & 240 & 120 & 0 & 120 & 0 & 0 \\
\hline Military & 360 & 120 & 0 & 240 & 0 & 0 \\
\hline Public & 1440 & 360 & 480 & 0 & 0 & 600 \\
\hline
\end{tabular}


Table 6 shows that the highest business trips per week generated from medium residential zones is attracted to commercial zones while the least number is attracted to industrial zones.

Table 6. Modal split for business trips with medium residential zone as origin

\begin{tabular}{|l|c|c|c|c|c|c|}
\hline \multirow{2}{*}{ Destination } & \multirow{2}{*}{$\begin{array}{c}\text { Trips per } \\
\text { week }\end{array}$} & $\begin{array}{c}\text { Private } \\
\text { vehicle }\end{array}$ & \multirow{2}{*}{ Trek } & \multicolumn{3}{|c|}{ Public transport } \\
\cline { 4 - 7 } & 2485 & 497 & 0 & 1491 & 0 & 497 \\
\hline $\begin{array}{l}\text { Low } \\
\text { Residential }\end{array}$ & 20377 & 2982 & 1491 & 9940 & 4473 & 994 \\
\hline $\begin{array}{l}\text { High } \\
\text { Residential }\end{array}$ & 29323 & 3976 & 994 & 16401 & 5467 & 2485 \\
\hline Commercial & 1988 & 994 & 0 & 497 & 497 & 0 \\
\hline Recreational & 1491 & 497 & 0 & 497 & 497 & 0 \\
\hline Educational & 994 & 497 & 0 & 0 & 0 & 0 \\
\hline Industrial & 2485 & 994 & 0 & 0 & 0 & 497 \\
\hline Military & 8449 & 2982 & 497 & 884 & 884 & 994 \\
\hline Public & & & & & & Motor cycle \\
\hline
\end{tabular}

It is evident from Table 7 that the highest number of non-business trips per week generated from medium residential zones is attracted to commercial zones and the least to educational zones. This can be adduced to the fact that trading activities in medium residential zones attract trips to commercial zones.

Table 7. Modal split for non-business trips with medium residential zone as origin

\begin{tabular}{|l|c|c|c|c|c|c|}
\hline Destination & $\begin{array}{c}\text { Trips per } \\
\text { week }\end{array}$ & $\begin{array}{c}\text { Private } \\
\text { vehicle }\end{array}$ & \multirow{2}{*}{ Trek } & \multicolumn{3}{|c|}{ Public transport } \\
\cline { 4 - 7 } & 4620 & 1680 & 0 & 7140 & 0 & 0 \\
\hline $\begin{array}{l}\text { Low } \\
\text { Residential }\end{array}$ & 5880 & 1620 & 840 & 2940 & 0 & 420 \\
\hline $\begin{array}{l}\text { High } \\
\text { Residential }\end{array}$ & 18900 & 5880 & 1680 & 6720 & 2100 & 2520 \\
\hline Commercial & 5460 & 1680 & 420 & 2100 & 1260 & 0 \\
\hline Recreational & 1680 & 420 & 0 & 840 & 420 & 0 \\
\hline Educational & 2100 & 420 & 0 & 1260 & 420 & 0 \\
\hline Industrial & 2520 & 420 & 0 & 2100 & 0 & 0 \\
\hline Military & 4200 & 1680 & 0 & 1680 & 0 & 840 \\
\hline Public & & & & & & Botor cycle \\
\hline
\end{tabular}


Table 8 shows that the highest number of business trips per week originating from high residential zones is attracted to commercial zones while the least is attracted to educational zones.

Table 8. Modal split for business trips with high residential zone as origin

\begin{tabular}{|l|c|c|c|c|c|c|}
\hline \multirow{2}{*}{ Destination } & \multirow{2}{*}{$\begin{array}{c}\text { Trips per } \\
\text { week }\end{array}$} & $\begin{array}{c}\text { Private } \\
\text { vehicle }\end{array}$ & \multirow{2}{*}{ Trek } & \multicolumn{3}{|c|}{ Public transport } \\
\cline { 5 - 7 } & & & Cab & Bus & Motor cycle \\
\hline $\begin{array}{l}\text { Low } \\
\text { Residential }\end{array}$ & 5467 & 1491 & 497 & 2982 & 0 & 497 \\
\hline $\begin{array}{l}\text { Medium } \\
\text { Residential }\end{array}$ & 15407 & 3479 & 1491 & 6958 & 1491 & 1988 \\
\hline Commercial & 35287 & 6958 & 2982 & 11928 & 4970 & 7455 \\
\hline Recreational & 3976 & 994 & 0 & 2485 & 497 & 0 \\
\hline Educational & 497 & 497 & 0 & 0 & 0 & 0 \\
\hline Industrial & 1988 & 497 & 0 & 994 & 497 & 0 \\
\hline Military & 1491 & 497 & 0 & 994 & 0 & 0 \\
\hline Public & 2982 & 994 & 0 & 1491 & 0 & 497 \\
\hline
\end{tabular}

Table 9 shows that he highest non-business trips per week from high residential zones is attracted to commercial zones while the least is attracted to industrial zones. This is because business activities in commercial zones always pull both business and non-business trips to it. The presence of hotels and other relaxation centers serve as "magnet" to trips particularly non-business trips.

Table 9. Modal split for non-business trips with high residential zone as origin

\begin{tabular}{|l|c|c|c|c|c|c|}
\hline \multirow{2}{*}{ Destination } & \multirow{2}{*}{$\begin{array}{c}\text { Trips per } \\
\text { week }\end{array}$} & $\begin{array}{c}\text { Private } \\
\text { vehicle }\end{array}$ & \multirow{2}{*}{ Trek } & \multicolumn{3}{|c|}{ Public transport } \\
\cline { 4 - 7 } & 15120 & 3360 & 840 & 9240 & 0 & 1680 \\
\hline $\begin{array}{l}\text { Low } \\
\text { Residential }\end{array}$ & 25200 & 4200 & 1260 & 15540 & 3360 & 840 \\
\hline $\begin{array}{l}\text { Medium } \\
\text { Residential }\end{array}$ & 27720 & 5040 & 4200 & 13020 & 0 & 5460 \\
\hline Commercial & 11340 & 2100 & 1680 & 5460 & 2100 & 0 \\
\hline Recreational & 10080 & 2100 & 0 & 5460 & 2520 & 0 \\
\hline Educational & 7140 & 1680 & 420 & 2940 & 1680 & 420 \\
\hline Industrial & 8400 & 1680 & 840 & 5040 & 0 & 2520 \\
\hline Military & 21000 & 6300 & 840 & 11340 & 0 & 840 \\
\hline Public & & & & & & Motor cycle \\
\hline
\end{tabular}


Table 10 shows that the highest number of business trips per week originating from commercial zones is attracted to industrial zones while the least is attracted to both low residential and military zones.

Table 10. Modal split for business trips with commercial zone as origin

\begin{tabular}{|l|c|c|c|c|c|c|}
\hline \multirow{2}{*}{ Destination } & \multirow{2}{*}{$\begin{array}{c}\text { Trips per } \\
\text { week }\end{array}$} & $\begin{array}{c}\text { Private } \\
\text { vehicle }\end{array}$ & \multirow{2}{*}{ Trek } & \multicolumn{3}{|c|}{ Public transport } \\
\cline { 4 - 7 } & 148 & 74 & 0 & 74 & 0 & Cab \\
\hline $\begin{array}{l}\text { Low } \\
\text { Residential }\end{array}$ & 592 & 148 & 0 & 370 & 74 & 0 \\
\hline $\begin{array}{l}\text { Medium } \\
\text { Residential }\end{array}$ & 1480 & 444 & 74 & 370 & 592 & 0 \\
\hline $\begin{array}{l}\text { High } \\
\text { Residential }\end{array}$ & & & & & & 0 \\
\hline Recreational & 1850 & 370 & 296 & 740 & 296 & 0 \\
\hline Educational & 1628 & 370 & 222 & 444 & 592 & 0 \\
\hline Industrial & 2146 & 296 & 0 & 1110 & 740 & 0 \\
\hline Military & 148 & 74 & 0 & 74 & 0 & 0 \\
\hline Public & 1110 & 444 & 0 & 518 & 0 & 148 \\
\hline
\end{tabular}

Table 11 shows that he highest non-business trips per week from commercial zones is attracted to high residential zones while the least is attracted to industrial zones.

Table 11. Modal split for non-business trips with commercial zone as origin

\begin{tabular}{|l|c|c|c|c|c|c|}
\hline \multirow{2}{*}{ Destination } & $\begin{array}{c}\text { Trips per } \\
\text { week }\end{array}$ & $\begin{array}{c}\text { Private } \\
\text { vehicle }\end{array}$ & \multirow{2}{*}{ Trek } & \multicolumn{3}{|c|}{ Public transport } \\
\cline { 4 - 7 } & 2840 & 496 & 0 & 1736 & 608 & 0 \\
\hline $\begin{array}{l}\text { Low } \\
\text { Residential }\end{array}$ & 4464 & 744 & 248 & 2232 & 1240 & 0 \\
\hline $\begin{array}{l}\text { Medium } \\
\text { Residential }\end{array}$ & 5456 & 1240 & 496 & 1736 & 1984 & 0 \\
\hline $\begin{array}{l}\text { High } \\
\text { Residential }\end{array}$ & 2480 & 744 & 0 & 1488 & 248 & 0 \\
\hline Recreational & 992 & 248 & 0 & 496 & 248 & 0 \\
\hline Educational & 476 & 248 & 0 & 0 & 228 & 0 \\
\hline Industrial & 992 & 248 & 0 & 744 & 0 & 0 \\
\hline Military & 2728 & 744 & 0 & 1488 & 0 & 496 \\
\hline Public & & & & & \\
\hline
\end{tabular}


Table 12 shows that the highest number of business trips per week generated from recreational zones is attracted to commercial zones while the least is attracted to both educational and industrial zones.

Table 12. Modal split for business trips with recreational zone as origin

\begin{tabular}{|l|c|c|c|c|c|c|}
\hline \multirow{2}{*}{ Destination } & \multirow{2}{*}{$\begin{array}{c}\text { Trips per } \\
\text { week }\end{array}$} & $\begin{array}{c}\text { Private } \\
\text { vehicle }\end{array}$ & \multirow{2}{*}{ Trek } & \multicolumn{3}{|c|}{ Public transport } \\
\cline { 4 - 7 } & 115 & 46 & 0 & 69 & 0 & Cab \\
\hline $\begin{array}{l}\text { Low } \\
\text { Residential }\end{array}$ & 184 & 46 & 0 & 115 & 23 & 0 \\
\hline $\begin{array}{l}\text { Medium } \\
\text { Residential }\end{array}$ & 230 & 69 & 0 & 138 & 0 & 23 \\
\hline $\begin{array}{l}\text { High } \\
\text { Residential }\end{array}$ & 23 & 115 & 46 & 207 & 0 & 0 \\
\hline Commercial & 368 & 23 & 0 & 0 & 0 & 0 \\
\hline Educational & 23 & 23 & 0 & 0 & 0 & 0 \\
\hline Industrial & 23 & 92 & 0 & 138 & 46 & 0 \\
\hline Military & 276 & 46 & 0 & 69 & 0 & 23 \\
\hline Public & 138 & & & & & 0 \\
\hline
\end{tabular}

Table 13 shows that he highest non-business trips per week from recreational zones is attracted to both commercial and educational zones while the least is attracted to low residential, medium residential and military zones.

Table 13. Modal split for non-business trips with recreational zone as origin

\begin{tabular}{|l|c|c|c|c|c|c|}
\hline \multirow{2}{*}{ Destination } & \multirow{2}{*}{$\begin{array}{c}\text { Trips per } \\
\text { week }\end{array}$} & $\begin{array}{c}\text { Private } \\
\text { vehicle }\end{array}$ & \multirow{2}{*}{ Trek } & \multicolumn{3}{|c|}{ Public transport } \\
\cline { 4 - 7 } & & & Cab & Bus & Motor cycle \\
\hline $\begin{array}{l}\text { Low } \\
\text { Residential }\end{array}$ & 99 & 0 & 0 & 99 & 0 & 0 \\
\hline $\begin{array}{l}\text { Medium } \\
\text { Residential }\end{array}$ & 99 & 0 & 0 & 60 & 39 & 0 \\
\hline $\begin{array}{l}\text { High } \\
\text { Residential }\end{array}$ & 1485 & 198 & 0 & 990 & 297 & 0 \\
\hline Commercial & 3960 & 693 & 198 & 2079 & 990 & 0 \\
\hline Educational & 3960 & 792 & 279 & 1782 & 108 & 0 \\
\hline Industrial & 297 & 99 & 0 & 198 & 9 & 0 \\
\hline Military & 99 & 0 & 0 & 99 & 396 & 0 \\
\hline Public & 2475 & 1089 & 0 & 990 & 0 & 0 \\
\hline
\end{tabular}


Table 14 shows that the highest number of business trips per week generated from educational zones is attracted to commercial zones while the least is attracted to military zones.

Table 14. Modal split for business trips with educational zone as origin

\begin{tabular}{|l|c|c|c|c|c|c|}
\hline \multirow{2}{*}{ Destination } & \multirow{2}{*}{$\begin{array}{c}\text { Trips per } \\
\text { week }\end{array}$} & $\begin{array}{c}\text { Private } \\
\text { vehicle }\end{array}$ & \multirow{2}{*}{ Trek } & \multicolumn{3}{|c|}{ Public transport } \\
\cline { 4 - 7 } & 90 & 45 & 0 & 45 & 0 & 0 \\
\hline $\begin{array}{l}\text { Low } \\
\text { Residential }\end{array}$ & 675 & 180 & 0 & 360 & 90 & 0 \\
\hline $\begin{array}{l}\text { Medium } \\
\text { Residential }\end{array}$ & 315 & 90 & 40 & 180 & 5 & 0 \\
\hline $\begin{array}{l}\text { High } \\
\text { Residential }\end{array}$ & 1864 & 316 & 0 & 803 & 745 & 0 \\
\hline Commercial & 965 & 194 & 70 & 532 & 169 & 0 \\
\hline Recreational & 185 & 56 & 55 & 56 & 18 & 0 \\
\hline Industrial & 81 & 81 & 0 & 0 & 0 & 0 \\
\hline Military & 350 & 116 & 0 & 234 & 0 & 0 \\
\hline Public & & & & & Motor cycle \\
\hline
\end{tabular}

Table 15 shows that the highest number of non-business trips per week from educational zones is attracted to commercial zones while the least is attracted to military zones.

Table 15. Modal split for non-business trips with educational zone as origin

\begin{tabular}{|l|c|c|c|c|c|c|}
\hline \multirow{2}{*}{ Destination } & \multirow{2}{*}{$\begin{array}{c}\text { Trips per } \\
\text { week }\end{array}$} & $\begin{array}{c}\text { Private } \\
\text { vehicle }\end{array}$ & \multirow{2}{*}{ Trek } & \multicolumn{3}{|c|}{ Public transport } \\
\cline { 4 - 7 } & 138 & 69 & 0 & 69 & 0 & 0 \\
\hline $\begin{array}{l}\text { Low } \\
\text { Residential }\end{array}$ & 276 & 69 & 0 & 138 & 69 & 0 \\
\hline $\begin{array}{l}\text { Medium } \\
\text { Residential }\end{array}$ & 1380 & 345 & 138 & 897 & 0 & 0 \\
\hline $\begin{array}{l}\text { High } \\
\text { Residential }\end{array}$ & 2070 & 483 & 0 & 1035 & 552 & 0 \\
\hline Commercial & 1380 & 207 & 69 & 621 & 483 & 0 \\
\hline Recreational & 207 & 69 & 69 & 69 & 0 & 0 \\
\hline Industrial & 69 & 69 & 0 & 0 & 0 & 0 \\
\hline Military & 414 & 138 & 0 & 276 & 0 & 0 \\
\hline Public & & & & & & 0 \\
\hline
\end{tabular}


Table 16 shows that the highest number of business trips per week generated from industrial zones is attracted to high residential zones while the least is attracted to commercial zones.

Table 16. Modal split for business trips with industrial zone as origin

\begin{tabular}{|l|c|c|c|c|c|c|}
\hline \multirow{2}{*}{ Destination } & \multirow{2}{*}{$\begin{array}{c}\text { Trips per } \\
\text { week }\end{array}$} & $\begin{array}{c}\text { Private } \\
\text { vehicle }\end{array}$ & \multirow{2}{*}{ Trek } & \multicolumn{3}{|c|}{ Public transport } \\
\cline { 4 - 7 } & 1818 & 365 & 0 & 1232 & 0 & 221 \\
\hline $\begin{array}{l}\text { Low } \\
\text { Residential }\end{array}$ & 3673 & 643 & 257 & 1646 & 730 & 397 \\
\hline $\begin{array}{l}\text { Medium } \\
\text { Residential }\end{array}$ & 3903 & 1010 & 395 & 1281 & 802 & 415 \\
\hline $\begin{array}{l}\text { High } \\
\text { Residential }\end{array}$ & 447 & 156 & 54 & 0 & 237 & 0 \\
\hline Commercial & 917 & 244 & 0 & 673 & 0 & 0 \\
\hline Recreational & 516 & 258 & 0 & 0 & 258 & 0 \\
\hline Educational & 809 & 136 & 0 & 673 & 0 & 0 \\
\hline Military & 2565 & 455 & 0 & 1724 & 0 & 386 \\
\hline Public & & & & & & Motor cycle \\
\hline
\end{tabular}

Table 17 shows that the highest number of non-business trips per week generated from industrial zones is attracted to military zones while the least is attracted to low residential zones.

Table 17. Modal split for non-business trips with industrial zone as origin

\begin{tabular}{|l|c|c|c|c|c|c|}
\hline \multirow{2}{*}{ Destination } & \multirow{2}{*}{$\begin{array}{c}\text { Trips per } \\
\text { week }\end{array}$} & $\begin{array}{c}\text { Private } \\
\text { vehicle }\end{array}$ & \multirow{2}{*}{ Trek } & \multicolumn{3}{|c|}{ Public transport } \\
\cline { 4 - 7 } & 276 & 138 & 0 & 138 & 0 & 0 \\
\hline $\begin{array}{l}\text { Low } \\
\text { Residential }\end{array}$ & 690 & 138 & 0 & 414 & 138 & 0 \\
\hline $\begin{array}{l}\text { Medium } \\
\text { Residential }\end{array}$ & 759 & 207 & 69 & 345 & 138 & 0 \\
\hline $\begin{array}{l}\text { High } \\
\text { Residential }\end{array}$ & 828 & 138 & 0 & 414 & 276 & 0 \\
\hline Commercial & 552 & 138 & 0 & 414 & 0 & 0 \\
\hline Recreational & 690 & 138 & 138 & 414 & 0 & 0 \\
\hline Educational & 1035 & 150 & 0 & 775 & 110 & 0 \\
\hline Military & 552 & 138 & 0 & 414 & 0 & 0 \\
\hline Public & & & & & & 0 \\
\hline
\end{tabular}


Table 18 shows that the highest number of business trips per week generated from military zones is attracted to commercial zones while the least is attracted to industrial zones.

Table 18. Modal split for business trips with military zone as origin

\begin{tabular}{|l|c|c|c|c|c|c|}
\hline \multirow{2}{*}{ Destination } & \multirow{2}{*}{$\begin{array}{c}\text { Trips per } \\
\text { week }\end{array}$} & $\begin{array}{c}\text { Private } \\
\text { vehicle }\end{array}$ & \multirow{2}{*}{ Trek } & \multicolumn{3}{|c|}{ Public transport } \\
\cline { 4 - 7 } & & & Cab & Bus & Motor cycle \\
\hline $\begin{array}{l}\text { Low } \\
\text { Residential }\end{array}$ & 73 & 0 & 0 & 73 & 0 & 0 \\
\hline $\begin{array}{l}\text { Medium } \\
\text { Residential }\end{array}$ & 345 & 59 & 46 & 161 & 0 & 69 \\
\hline $\begin{array}{l}\text { High } \\
\text { Residential }\end{array}$ & 598 & 115 & 0 & 483 & 0 & 0 \\
\hline Commercial & 690 & 92 & 46 & 506 & 46 & 0 \\
\hline Industrial & 69 & 46 & 0 & 23 & 0 & 0 \\
\hline Recreational & 138 & 46 & 0 & 92 & 0 & 0 \\
\hline Educational & 115 & 23 & 0 & 92 & 0 & 0 \\
\hline Public & 230 & 69 & 0 & 138 & 0 & 23 \\
\hline
\end{tabular}

Table 19 shows that the highest number of non-business trips per week generated from industrial zones is attracted to commercial zones while the least is attracted to both industrial and educational zones.

Table 19. Modal split for non-business trips with military zone as origin

\begin{tabular}{|l|c|c|c|c|c|c|}
\hline \multirow{2}{*}{ Destination } & \multirow{2}{*}{$\begin{array}{c}\text { Trips per } \\
\text { week }\end{array}$} & $\begin{array}{c}\text { Private } \\
\text { vehicle }\end{array}$ & \multirow{2}{*}{ Trek } & \multicolumn{3}{|c|}{ Public transport } \\
\cline { 4 - 7 } & 148 & 74 & 0 & 74 & 0 & Cab \\
\hline $\begin{array}{l}\text { Low } \\
\text { Residential }\end{array}$ & 296 & 74 & 0 & 148 & 74 & 0 \\
\hline $\begin{array}{l}\text { Medium } \\
\text { Residential }\end{array}$ & 1110 & 296 & 0 & 518 & 296 & 0 \\
\hline $\begin{array}{l}\text { High } \\
\text { Residential }\end{array}$ & 3700 & 740 & 74 & 666 & 2220 & 0 \\
\hline Commercial & 74 & 74 & 0 & 0 & 0 & 0 \\
\hline Industrial & 518 & 148 & 0 & 296 & 74 & 0 \\
\hline Recreational & 74 & 74 & 0 & 0 & 0 & 0 \\
\hline Educational & 444 & 148 & 0 & 222 & 0 & 74 \\
\hline Public & & & & & & 0 \\
\hline
\end{tabular}


Table 20 shows that the highest number of business trips per week generated from public zones is attracted to industrial zones while the least is attracted to military zones.

Table 20. Modal split for business trips with public zone as origin

\begin{tabular}{|l|c|c|c|c|c|c|}
\hline \multirow{2}{*}{ Destination } & \multirow{2}{*}{$\begin{array}{c}\text { Trips per } \\
\text { week }\end{array}$} & $\begin{array}{c}\text { Private } \\
\text { vehicle }\end{array}$ & \multirow{2}{*}{ Trek } & \multicolumn{3}{|c|}{ Public transport } \\
\cline { 5 - 7 } & 8678 & 1984 & 494 & 5456 & 0 & 744 \\
\hline $\begin{array}{l}\text { Low } \\
\text { Residential }\end{array}$ & 10895 & 1967 & 1240 & 6944 & 0 & 744 \\
\hline $\begin{array}{l}\text { Medium } \\
\text { Residential }\end{array}$ & 7688 & 1984 & 496 & 4464 & 0 & 744 \\
\hline $\begin{array}{l}\text { High } \\
\text { Residential }\end{array}$ & 15624 & 2480 & 2232 & 7936 & 2480 & 496 \\
\hline Commercial & 21824 & 3224 & 0 & 11160 & 7440 & 0 \\
\hline Industrial & 2722 & 248 & 0 & 1730 & 744 & 0 \\
\hline Recreational & 3276 & 796 & 248 & 992 & 1240 & 0 \\
\hline Educational & 1488 & 248 & 248 & 992 & 0 & 0 \\
\hline Military & & & & & & Motor cycle \\
\hline
\end{tabular}

Table 21 shows that the highest number of non-business trips per week generated from industrial zones is attracted to commercial zones while the least is attracted to military zones.

Table 21. Modal split for non-business trips with public zone as origin

\begin{tabular}{|l|c|c|c|c|c|c|}
\hline \multirow{2}{*}{ Destination } & \multirow{2}{*}{$\begin{array}{c}\text { Trips per } \\
\text { week }\end{array}$} & $\begin{array}{c}\text { Private } \\
\text { vehicle }\end{array}$ & \multirow{2}{*}{ Trek } & \multicolumn{3}{|c|}{ Public transport } \\
\cline { 4 - 7 } & 1395 & 315 & 180 & 720 & 0 & 450 \\
\hline $\begin{array}{l}\text { Low } \\
\text { Residential }\end{array}$ & 180 & 45 & 0 & 45 & 0 & 90 \\
\hline $\begin{array}{l}\text { Medium } \\
\text { Residential }\end{array}$ & 540 & 180 & 0 & 315 & 0 & 45 \\
\hline $\begin{array}{l}\text { High } \\
\text { Residential }\end{array}$ & 1620 & 450 & 45 & 720 & 0 & 405 \\
\hline Commercial & 135 & 90 & 0 & 45 & 0 & 0 \\
\hline Industrial & 360 & 135 & 0 & 180 & 0 & 45 \\
\hline Recreational & 90 & 45 & 0 & 45 & 0 & 0 \\
\hline Educational & 45 & 45 & 0 & 0 & 0 & 0 \\
\hline Military & & & & & & Motor cycle \\
\hline
\end{tabular}

An appraisal of Tables 4 to 21 shows that the zone with the highest total number of business and nonbusiness trips terminating therein is the commercial zone with 90,215 trips. This result is anticipated as commercial zones are the 'hub' or 'central zones' of cities which attract a lot of activities. Hence, such zones need to be provided with well laid out network of roads for easy access by other zones. 


\subsection{CONCLUSION}

Based on the results of analysis carried out in this study, it is reasonable to conclude that the number of persons per household and the number of households in various zones have direct proportionality to the number of business and non-business trips generated per week in Ado-Ekiti. Similarly, land-use activities have considerable effect on both business and non-business trips attracted per week. The closeness in distance between one zone and the other has a direct proportionality to the number of trips attracted per week. The study also shows that there is a direct proportionality between the level of income of households and the ownership of cars.

The outcomes of this study showed that land-use and socio-economic factors have considerable effect on trip making behavior of commuters within Ado-Ekiti. It is therefore recommended that the outcomes of this study be used for future planning of Ado-Ekiti's transportation system.

\subsection{ACKNOWLEDGEMENT}

The author would like to thank the final year students (2018/2019 set) of the Civil Engineering Department, Federal University of Technology Akure quite a number of (but too numerous to mention all their names) who helped in collecting information used in the analysis.

\section{REFERENCES}

[1] Ogunleye, O. S., 2014. Urban mobility in Ekiti State: Options for transformation. American International Journal of Social Science. Vol 3, No 5, pp. 200-206

[2] Engstrom, R., 2016. The roads role in the freight transport system. Transportation Research Procedia. No 14, pp. 1443-1452

[3] Pandya, R. J., and Katti, B. K., 2012. Dynamism of transportation and land use interaction in urban context. International Journal of Advancements in Research \& Technology. Vol 1, No 5, pp. 1-5

[4] Wang, Y., Wu, B., Dong, Z., and Ye, X., 2016. A joint modeling analysis of passengers' intercity travel destination and mode choices in Yangtze River Delta Megaregion of China. Hindawi Mathematical Problems in Engineering. Vol 2016, Article ID No 5293210, pp. 1-10

[5] Ahmed, B., 2012. The traditional four steps transportation modeling using simplified transport network: A case study of Dhaka City, Bangladesh. International Journal of Advanced Science, Engineering, Technology and Research. Vol 1, No 1, pp. 19-40

[6] Chang, J. S., Jung, D., Kim, J., and Kang, T., 2014. Comparative analysis of trip generation models: Results using home-based work trips in the Seoul Metropolitan Area. Transportation Letters The International Journal of Transportation Research. Vol 6, No 2, pp. 78-88

[7] Faizi, A. J., Juremalani, J. R., Bagadia, S., and Juremalani, D., 2019. A critical appraisal of mode choice model of work trips. International Journal of Engineering and Advanced Technology. Vol 9, No 1, pp. 1766-1770

[8] Saw, K., Katti, B. K., and Joshi, G., 2015. Literature review of traffic assignment: Static and dynamic. International Journal of Transportation Engineering. Vol 2, No 4, pp. 339-347

[9] Pojani, D., and Stead, D., 2015. Sustainable urban transport in the developing world: Beyond megacities. Sustainability. Vol 7, No 6, pp. 7784-7805

[10] Davison, L., Enoch, M, Ryley, T., Quddus, M., and Wang, C., 2014. A survey of demand responsive transport in Great Britain. Transport Policy. Vol 31, pp. 47-54

[11] Oduwaye, L., Alade, W., and Adekunle, S., 2011. Land use and traffic pattern along Lagos Badagry corridor, Lagos, Nigeria. Proceedings Realcorp. pp. 525-532.

[12] Gim, T. T., 2018. An analysis of the relationship between land use and weekend travel: Focusing on the internal capture of trips. Sustainability. Vol 10, No 2, pp. 1-17 